\title{
Proof of concept centers: accelerating the commercialization of university innovation
}

\author{
Christine A. Gulbranson • David B. Audretsch
}

Published online: 8 February 2008

(C) Springer Science+Business Media, LLC 2008

\begin{abstract}
Innovation drives economic growth. Economic growth leads to longer, healthier lives by transforming yesterday's luxuries into better, cheaper, and more efficient goods and services. University research is a key component of our nation's innovative capacity. In an increasingly dynamic and global economy, the institutional infrastructure is inefficient at moving university innovations to the marketplace. University researchers often face convoluted procedures with insufficient guidance to commercialize their innovations. As angel investors and venture capitalists increasingly invest in later stage enterprises (See PricewaterhouseCoopers, and National Venture Capital Association. MoneyTree ${ }^{T M}$ survey report. 2007. and VentureOne, "Venture Capital Industry Report." DowJones 2006), researchers face difficulty finding early stage funding to develop and test prototypes and conduct market research. In order to fill this funding gap and accelerate the commercialization of university innovations, a new type of organization has emerged - the proof of concept center. An analysis of the Deshpande Center at MIT and the von Liebig Center at UCSD provides valuable insight into how proof of concept centers can facilitate the transfer of university innovations into commercial applications.
\end{abstract}

Keywords Innovation - Research and development - Scientists · Entrepreneurship · Venture capital

JEL Classifications $03 \cdot$ L26

C. A. Gulbranson

The Kauffman Foundation, Kansas City, MO, USA

e-mail: cgulbranson@kauffman.org

D. B. Audretsch ( $\square)$

Max Planck Institute of Economics, Jena, Germany

e-mail: audretsch@econ.mpg.de

D. B. Audretsch

Indiana University, Bloomington, IN, USA 


\section{Introduction}

Globalization has shifted the competitiveness of leading developed economies away from standardized manufacturing activities towards knowledge-based industries and services (Friedman 2005). As Thurow (2002, pp. 38-39) observes, "The world is moving from an industrial era based on natural resources into a knowledge-based era based on skill, education, and research and development." Knowledge has emerged as a crucial source of employment and economic growth in the global economy because it is the basis for innovation. ${ }^{1}$

Where does the crucial resource of knowledge come from? While investments by private firms in research and development $(\mathrm{R} \& \mathrm{D})$ are a crucial source of knowledge, so too are investments made in research and education at universities. However, as Senator Birch Bayh observed some three decades ago, investments in university research do not automatically spill over to generate innovative activity and economic growth. "A wealth of scientific talent at American colleges and universities-talent responsible for the development of numerous innovative scientific breakthroughs each year-is going to waste as a result of bureaucratic red tape and illogical government regulations..."2 Audretsch et al. (2006) suggest that it is the knowledge filter that stands between investment in university research on the one hand, and its commercialization through innovation, leading ultimately to economic growth, on the other.

Seen through the eyes of Senator Bayh, the magnitude of the knowledge filter is daunting, "What sense does it make to spend billions of dollars each year on governmentsupported research and then prevent new developments from benefiting the American people because of dumb bureaucratic red tape?"3

Thus, if university research does not passively spill over for commercialization and innovation, then institutions are needed to facilitate the spillover of university research. As Litan, Mitchell and Reedy (2007, p. 57) emphasize, "A perennial challenge related to university/driven innovation has been to ensure that university structures help, not hinder, innovation and its commercialization."

The purpose of this paper is to examine two important examples of institutions devoted towards facilitating the spillover and commercialization of university research, the Deshpande Center at MIT and the von Liebig Center at the University of California San Diego (UCSD). Both of these centers are mechanisms designed to fill the "funding gap" of seed stage investing as angel investors and venture capital funds shift their focus to larger and later stage investments (Fishback et al. 2007). In order to fill this funding gap and accelerate the commercialization of university innovations, a new type of organization has emerged - the proof of concept center.

The proof of concept center accelerates the commercialization of innovations out of the university and into the marketplace. It does this by providing seed funding to novel, earlystage research that most often would not be funded by any other conventional source. Unlike some accelerators, there is no central shared laboratory space; each of the funded investigators continues to perform their research in their own respective laboratories. The proof of concept center facilitates and fosters the exchange of ideas between the university innovators and industry via various mentors associated with the center. An analysis of the

\footnotetext{
1 Investments in knowledge are the driving force of economic growth in Romer (1986) and Lucas (1993).

2 Introductory statement of Birch Bayh, September 13, 1978, cited from the Association of University Technology Managers Report (AUTM) (2004, p. 5).

3 Statement by Birch Bayh, April 13, 1980, on the approval of S. 414 (Bayh-Dole) by the U.S. Senate on a 91-94 vote, cited from (AUTM 2004, p. 16).
} 
Deshpande Center at MIT and the von Liebig Center at UCSD provides valuable insight into how proof of concept centers can facilitate the transfer and spillover of university research into innovative activity and commercial applications.

\section{The von Liebig Center at UCSD}

In 2001, the William J. von Liebig Foundation awarded UCSD's Jacobs School of Engineering a $\$ 10$ million gift in order to create the William J. von Liebig Center. The von Liebig Center's stated mission is "to accelerate the commercialization of UCSD innovations into the marketplace, foster and facilitate the exchange of ideas between the University and industry, and prepare engineering students for the entrepreneurial workplace." 4 In order to accomplish these goals, the Center uses three complimentary approaches: seed funding, advisory services, and educational programs.

\subsection{Seed funding}

The von Liebig Center provides seed funding ranging from $\$ 15,000$ to $\$ 75,000$ to support the commercialization of UCSD discoveries with near-term market prospects. These funds are not used for basic research, but rather to evaluate the commercial potential of existing research. Von Liebig funding allows recipients to focus on development, testing, or prototype construction, and/or conduct specific market research. This evaluation may lead to industry collaboration, licensing, the formation of a new company, or the abandonment of the technology for commercial application.

The von Liebig Center typically funds ten to twelve projects annually, which ranged from $35-60 \%$ of the proposals submitted to the center. In order to be considered for funding, a project must include at least one Jacobs School of Engineering faculty member. ${ }^{5}$ The first step in the funding process is to submit a Statement of Intent, ${ }^{6}$ which outlines the project. After the Statement of Intent is submitted, the Center Commercialization Director assigns an advisor to the faculty member to help prepare the proposal and presentation to the review panel. The following month the full funding application ${ }^{7}$ is submitted. A five to eight member review panel, with both technical and business expertise, then reviews the application. The review panel recommends candidates to the Center based on the technology's novelty and need, the potential market size, the market definition, the technology's maturity, the utility of the grant, the intellectual property position, and the Principle Investigator's credibility. The final funding decision is made with input from Advisors and Center Staff.

\footnotetext{
${ }^{4}$ From the Center's website, available at http://www.vonliebig.ucsd.edu/about/mission.shtml.

${ }^{5}$ The center will work with researchers in other disciplines to find a partner in the Jacobs school who may be interested in collaboration. The Center is planning to expand beyond the Engineering school to engage researchers across the campus in 2008.

${ }^{6}$ A Statement of Intent includes the name of the Principle Investigator (PI), the project title, and a brief outline of up to 500 words describing the project.

7 The full funding application requests that the PI describe the project goals, the project plan, the commercialization potential of the technology, the backgrounds of the team members, any intellectual property associated with the technology, and a preliminary budget summary. The budget may include only direct project expenses, including the salaries and fees of graduate and undergraduate students, but may not include faculty salaries, patent and legal costs, UCSD overhead costs, or equipment costs over $\$ 5,000$.
} 
After a grant is awarded, a von Liebig advisor works with the principle investigator to prepare a commercialization plan that includes technical and business milestones as well as the budget needed to complete the milestones over a period of twelve months. The advisor then requests the authorization of funds corresponding to the first milestone from the commercialization director. Further payments are contingent on reaching established milestones. Upon completion of the project, PIs are requested to submit a two-page summary of the major findings of the project.

\subsection{Advisory services}

As of 2007 the von Liebig Center had six paid advisors ${ }^{8}$ that work at the Center part-time These advisors support approximately ten projects each. Advisors are selected based on their backgrounds in a technical discipline, having considerable experience in start-up and early stage technology ventures, and possessing significant connections to local companies and investment sources. These connections are extremely valuable because they link the technology and researchers to important external networks. The Advisors and Center staff work in partnership with representatives from the university technology transfer office (TechTIPS) who are responsible for protecting the intellectual property, and negotiating and executing the license agreements to the startups or licensees. The Center also works in coordination with external community organizations (CONNECT, Tech Coast Angels, and others to coach, offer guidance and to identify entrepreneurs and investment capital that will help the nascent companies move down the commercialization pipeline. The von Liebig Center makes these advisory services available to all researchers at the Jacobs School even if they do not receive funding from the Center. The Center also provides incubation space and needed meeting locations for pre-companies to operate before they secure capital and execute the license agreement.

\subsection{Educational programs}

The Center's educational programs can be divided into three categories: courses, lectures and seminars, and conferences. The von Liebig Center currently supports four graduate level courses ${ }^{9}$ designed by engineers to prepare students for the challenges of an entrepreneurial work environment. Instructors with both academic and industry experience teach these courses. Approximately 400 students have completed one or more of the courses and a small number of students have also had the opportunity to work for the Center as interns. Of these, at least ten have started companies, and another six have gone into non-traditional fields, such as technology investment banking and strategy consulting.

The Center hosts lectures and seminars to educate students, faculty, and researchers. The Center's most prominent series is the von Liebig Forum, which brings in high-profile innovators from industry and academia to give presentations and interviews.

\footnotetext{
${ }^{8}$ The Center's current six advisors are Hal DeLong (Life Sciences), Mike Elconin (IT), Steve Flaim (Life Sciences), Roger Moyers (IT/Materials), Jack Savidge (Structural Materials) and Mary Zoeller (IT).

9 The Center offers four courses: ENG 201-Venture Mechanics, ENG202-Enterprise Dynamics, ENG203Applied Innovation, and ENG207-Corporate Entrepreneurship for Global Competitiveness. Detailed information for these courses is available on the Center's website at http://www.vonliebig.ucsd.edu/ education/education_courses/.
} 
The von Liebig Center also hosts conferences for faculty, researchers, and graduate students such as the National Collegiate Inventors and Innovator Alliance's "Invention to Venture" conference in San Diego. These educational programs are all designed to further the student and faculty levels of awareness, education and familiarity with relevant and practical issues related to early stage commercialization.

\section{The Deshpande Center at MIT}

The Deshpande Center was founded at the MIT School of Engineering in 2002 from an initial $\$ 17.5$ million donation by Jaishree and Gururaj Deshpande. The center was created with the mission to increase the impact of MIT technologies on the marketplace. The Deshpande Center achieves its mission through the Grant Program, Catalyst Program, Innovation Teams (I-Teams) and Events. ${ }^{10}$

\subsection{Grant program}

The Deshpande Center provides up to $\$ 250,000$ to prepare MIT technology projects for commercialization. The Center holds two rounds of grant proposals each year and awards two types of grants. The Deshpande Center provides Ignition Grants (up to \$50,000) for novel projects that may be used for exploratory experiments and proof of concept. Innovation Grants (up to $\$ 250,000$ ) are also awarded to take an innovation into full development. Innovation Grants are only awarded once a project has established proof of concept and has identified an R\&D path and an IP strategy. This allows a project to attract venture capitalists or companies interested in investing in its technology.

The Deshpande Center typically awards sixteen grants each year, ${ }^{11}$ which is approximately 18 percent of the proposals submitted to the center. ${ }^{12}$ Originally the Center was exclusively focused on research created in the School of Engineering, but in spring 2005 the Center began accepting proposals from all MIT faculty. A multidisciplinary committee selected from inside the Institute and from the Catalyst (mentors) program evaluates all applications. After the committee recommends grant candidates, a catalyst is assigned to each project and a full proposal is submitted. ${ }^{13}$ Grant recipients are required to participate in the Catalyst Program, attend Center events, establish IP if appropriate, communicate the project's progress through various means, and avoid conflicts of interest.

\subsection{Catalyst program}

Unlike the von Liebig Center, the Deshpande Center uses volunteers to provide advisory services through its Catalyst Program. The center has approximately 50 Catalysts with

\footnotetext{
${ }^{10}$ From the Center's website, available at http://web.mit.edu/deshpandecenter/about.html.

11 Fourteen projects have been awarded multiple grants.

12 Since 2002, 64 projects have been funded out of over 365 reviewed proposals.

13 The full proposal is similar to the von Liebig proposal and should be no longer than ten pages in length and includes an executive summary, the market opportunity of the innovation, the proposed approach to innovation, the commercialization process, the impact of the technology, similar or previous technologies, the progress to date of the research, the research plan and milestones, resources and budget, other funding provided, team and collaboration information, and a budget proposal.
} 
technology innovation and entrepreneurial experience. Catalysts do not represent any company interests; they provide mentorship and assistance to MIT research teams in order to facilitate the commercialization process. Catalysts also agree to keep discussions in confidence and manage conflict of interest.

\subsection{Innovation teams and events}

The educational aspect of the Deshpande Center is divided into events and Innovations Teams. The Center hosts several events for grant recipients including IdeaStream, Open House, and the Catalyst Party. IdeaStream is an annual networking event that showcases MIT technologies to venture capitalists, entrepreneurs, and other researchers. Open House and the Catalyst Party are informal events that promote the exchange of ideas and the formation of new collaborations.

The Center's involvement in Innovation Teams (I-Teams) is part of a three-way partnership with the School of Engineering and the MIT Entrepreneurship Center. The I-Teams program is open to graduate students across MIT and is always filled. Six Deshpande grantees are chosen to be part of the I-Teams program each year and are given the opportunity to work with student teams to discover and define their commercialization plan. Data is not available to assess the number of I-team participants who pursue entrepreneurial careers after graduation.

\section{Comparing and evaluating the centers}

Table 1 provides a comparison between the Deshpande and von Liebig Centers. While both centers were initially funded from philanthropic donations, the initial funding of the Deshpande Center was $75 \%$ greater than for the von Liebig Center. However, both centers have funded about the same number of projects.

There are many obstacles in evaluating the performance of the two centers with respect to quantitative metrics of success. First, both centers have only been in existence for approximately five years; thus, there has not been enough time to evaluate the end result of many projects. Second, there are no accepted benchmarks to define success. While the formation of a business or the licensing of a technology are easy to identify as successes, it is difficult to determine failures. For example, if a researcher receives funding and ultimately discovers that there is no clear market opportunity for a particular technology, this allows the researcher to obtain quicker feedback and begin working on new technologies. Furthermore, there is no quantitative way to measure how much faster a particular technology reached the market by using a center or other intangibles such as the likelihood that a student will pursue an entrepreneurial endeavor later in life as a result of involvement with a center sponsored course, lecture, seminar, or project. Third, as is typical of entrepreneurship promotion programs, there are no clearly defined time expectations for proposals to come to fruition. Certain technologies require more time than others to develop and cross industry comparisons must account for market conditions that are unique to each industry.

Despite these difficulties in precise measurements, there are many clear indications of success at the von Liebig Center and Deshpande Center. Both centers exhibit a welldefined organizational structure that provides capital, guidance, and contacts to university innovators. This basic framework accelerates the commercialization process because it 
Table 1 Comparison between the von Liebig and Deshpande Centers as of November 2007

\begin{tabular}{|c|c|c|}
\hline & The von Liebig Center & The Deshpande Center \\
\hline Location & UCSD_Jacobs School of Engineering & MIT_School of Engineering \\
\hline \multirow[t]{2}{*}{ Initial Funding } & $\$ 10$ million & $\$ 17.5$ million \\
\hline & $\begin{array}{l}\text { Gift in } 2001 \text { from the William J. von Liebig } \\
\text { Foundation }\end{array}$ & $\begin{array}{l}\text { Donation in } 2002 \text { from Jaishree and } \\
\text { Gururaj Deshpande }\end{array}$ \\
\hline \multirow[t]{4}{*}{ Budget } & $\sim \$ 1.2$ million per year & $\sim \$ 1.7$ million per year \\
\hline & - Administrative staff $\sim \$ 475 \mathrm{~K}$ & - Administrative Staff $\sim \$ 320 \mathrm{~K}$ \\
\hline & - Grants \$420 K & - Grants $\sim \$ 1.3 \mathrm{M}$ \\
\hline & $\begin{array}{l}\text { - Advisors' salary } \sim \$ 240 \mathrm{~K} \\
\text { - Academic courses } \sim 45 \mathrm{~K}\end{array}$ & - Operational expenses $\sim \$ 80 \mathrm{~K}$ \\
\hline \multirow{2}{*}{$\begin{array}{l}\text { Amount of } \\
\text { grants }\end{array}$} & \multirow[t]{2}{*}{ Seed funding $-\$ 15-\$ 75 \mathrm{~K}$} & Ignition grants $-\leq \$ 50 \mathrm{~K}$ \\
\hline & & Innovation grants $-\leq \$ 250 \mathrm{~K}$ \\
\hline $\begin{array}{l}\text { Total amount } \\
\text { of grants } \\
\text { awarded }\end{array}$ & Over $\$ 2.8$ million & Over $\$ 7$ million \\
\hline \multirow{3}{*}{$\begin{array}{l}\text { Number of } \\
\text { proposals } \\
\text { funded }\end{array}$} & 66 projects & $\begin{array}{l}64 \text { projects (78 grants, } 39 \text { ignition grants, } \\
39 \text { innovation grants) }\end{array}$ \\
\hline & Approximately 11 grants per year & Approximately 16 grants per year \\
\hline & $35-60 \%$ approval rate of proposals & $\begin{array}{l}\text { Approximately } 18 \% \text { approval rate of } \\
\text { proposals }\end{array}$ \\
\hline $\begin{array}{l}\text { Time period of } \\
\text { accepting } \\
\text { proposals }\end{array}$ & $1-2$ proposal rounds per year (spring and fall) & $\begin{array}{l}2 \text { proposal rounds per year (spring and } \\
\text { fall) }\end{array}$ \\
\hline \multirow[t]{2}{*}{$\begin{array}{l}\text { Advisory } \\
\text { services }\end{array}$} & $\begin{array}{l}6 \text { Advisors work at the center approximately } 1 \\
\text { day a week }\end{array}$ & $\begin{array}{l}\text { Pool of } 50 \text { volunteers that are assigned as } \\
\text { advisors in the catalyst program }\end{array}$ \\
\hline & $\begin{array}{l}\text { Advisory services available to all faculty and } \\
\text { research staff at Jacobs School independent } \\
\text { of funding considerations }\end{array}$ & \\
\hline \multirow[t]{5}{*}{$\begin{array}{l}\text { Networking } \\
\text { events }\end{array}$} & $\begin{array}{l}\text { The "von Liebig Forum: Profiles in } \\
\text { Innovation"--speaker series that showcases } \\
\text { entrepreneurs, scientists, and innovators }\end{array}$ & $\begin{array}{l}\text { IdeaStream Symposium-networking } \\
\text { event for grant recipients, venture } \\
\text { capitalists, entrepreneurs, and other } \\
\text { researchers }\end{array}$ \\
\hline & $\begin{array}{l}\text { Open house-informal gathering for UCSD } \\
\text { and business community }\end{array}$ & $\begin{array}{l}\text { Open house-informal gathering for MIT } \\
\text { and business community }\end{array}$ \\
\hline & $\begin{array}{l}\text { Community workshops-i.e. IP transfer } \\
\text { between University and Industry }\end{array}$ & $\begin{array}{l}\text { Catalyst party-informal gathering of } \\
\text { grant recipients and catalysts }\end{array}$ \\
\hline & $\begin{array}{l}\text { Lunches-Awardee luncheon/networking } \\
\text { event }\end{array}$ & $\begin{array}{l}\text { Other optional events including ignition } \\
\text { forum, joint seminars with student } \\
\text { groups, and teambuilding events }\end{array}$ \\
\hline & $\begin{array}{l}\text { Other events including seminars and additional } \\
\text { speaker/presentation events }\end{array}$ & \\
\hline \multirow[t]{2}{*}{$\begin{array}{r}\text { Educational } \\
\text { programs }\end{array}$} & $\begin{array}{l}4 \text { Graduate level courses to introduce } \\
\text { engineering students to entrepreneurism } \\
\text { (Venture Mechanics, Enterprise Dynamics, } \\
\text { Applied Innovation, Corporate } \\
\text { Entrepreneurship for Global } \\
\text { Competitiveness) }\end{array}$ & $\begin{array}{l}\text { I-Teams Course-Collaboration with } \\
\text { MIT Entrepreneurship Center that } \\
\text { consists of teams with 3-5 science, } \\
\text { engineering, and management graduate } \\
\text { students evaluating the commercial } \\
\text { feasibility of innovation research } \\
\text { emerging from MIT research labs }\end{array}$ \\
\hline & $\begin{array}{l}\text { Over } 400 \text { students and graduate student interns } \\
\text { have enrolled in at least one of these courses }\end{array}$ & \\
\hline
\end{tabular}


Table 1 continued

\begin{tabular}{|c|c|c|}
\hline & The von Liebig Center & The Deshpande Center \\
\hline $\begin{array}{l}\text { Number of } \\
\text { startups and } \\
\text { licenses }\end{array}$ & 16 startups, 4 licenses & 10 startups, 1 license \\
\hline $\begin{array}{l}\text { Number of } \\
\text { employees in } \\
\text { startups }\end{array}$ & $64+$ & $150+$ \\
\hline $\begin{array}{l}\text { Capital } \\
\text { leverage }\end{array}$ & $\begin{array}{l}\text { Spinouts have acquired over } \$ 71 \text { million } \\
\text { in private capital }\end{array}$ & $\begin{array}{l}\text { Spinouts have acquired } \$ 88.7 \text { million } \\
\text { in private capital }\end{array}$ \\
\hline Sustainability & $\begin{array}{l}\text { Percentage of University royalty income from } \\
\text { the commercialization of any technologies } \\
\text { that receive Center services, University } \\
\text { support and private donations, targeting } \$ 2 \\
\text { million by } 2008 \text { and } \$ 10 \text { million by } 2010\end{array}$ & $\begin{array}{l}\text { Donations from companies that have } \\
\text { spun out } \\
\text { Future private donations }\end{array}$ \\
\hline
\end{tabular}

provides customizable support for researchers and fills an early-stage funding gap. Anecdotal evidence via interviews supports this claim. For example, one project interviewed was denied funding from a governmental agency yet received funding from the proof of concept center. The proof of concept center funding allowed the concept to be proved. Once this occurred many outside investors became interested in funding the project's further development. Furthermore, the success of the centers can be seen in the power they have given grantees to leverage more capital for their technologies. By legitimizing a researcher's technology, both centers have enabled and accelerated the acquisition of private capital for university technology. Together the centers have awarded nearly $\$ 10$ million in grants and have already seen 26 spinout companies accumulate over $\$ 159$ million in capital.

There are also areas where both centers can improve their efficiency and usefulness. Some participants felt that the Catalysts provided by the Deshpande Center were not appropriate for their technology. This might be a sign that the von Liebig Center model of paying advisors ensures that they provide better assistance. Some participants also questioned the amount and number of proposals funded by each center as being too few, but in general respondents spoke positively about both centers.

\section{Conclusions}

Both the von Liebig and Deshpande centers originally focused on the cultivation of innovation in the engineering schools. This concentration allowed the centers to maximize their effectiveness by limiting the areas of expertise needed by advisors. Attempting to fund proposals from multiple disciplines creates the need for a center to have advisors who are experts in multiple fields, but neglecting non-engineering disciplines does not yield the maximum impact in terms of commercialization. This also creates a challenge in determining which proposals to fund since comparing prospective technological innovations among disciplines is difficult without extensive knowledge of all the fields that could submit proposals. Perhaps the most important cost for these centers is the opportunity cost of the proposals they choose not to fund. By limiting the proposals to the school of engineering, a proof of concept center can minimize missed opportunities resulting from 
selection bias with review boards only funding technologies they are familiar with. However, this concerted approach comes at the cost of missing opportunities to fund technologies that originate outside the engineering schools. The von Liebig Center has combined the need for a concerted approach with a desire to fund the best technologies at the university by opening proposals to all UCSD faculty members but requiring them to partner with a Jacobs School of Engineering faculty member. The Deshpande Center has opened proposals to all MIT faculty members, which necessarily increases the difficulty of proposal evaluation.

In order to replicate and improve on the successes of the von Liebig and Deshpande Centers, it is important to understand the unique conditions that allowed each to prosper. Both centers benefit from locating at universities that excel in research and are located within a strong network of angel investors and venture capitalists. It is important to recognize that the strength of both centers comes from providing far more than capital. Both centers combine seed funding with advisory services, educational initiatives, and plug innovators into outside funding and collaboration networks. This unified approach is vital to ensure the commercialization of university technology because each component is complimentary.

With this in mind, the creation of a new proof of concept center must be located in a university that (1) produces innovative and marketable technology, (2) is not adverse to collaboration with external networks and groups, and (3) has technology transfer offices that are willing to work with a center to assist in the commercialization process. Furthermore, locating the center in the engineering school, at least initially, allows the center to focus its efforts on research that has a greater likelihood of translation into products.

The proof of concept center must also be able to find an administrative team and advisors who are "hubs" in the local venture capital, technology, and industry networks. The localized knowledge of a center's staff may actually be more useful in accelerating the commercialization of university technology than the seed funding. It is also important that a strong social network exists in the surrounding community including advisors, angel investors, venture capitalists, and interested firms for grantees to partner with. This component is necessary to allow proof of concept centers to invest in risky or unproven technologies with the realization that an outside supportive infrastructure is present for further development and commercialization. By providing the initial seed funding to reach proof of concept, these centers allow researchers the ability to then obtain follow-on funding.

With these considerations in mind, there are a number of locations that may be best suited for new proof of concept center including, but not limited to UT-Austin, Johns Hopkins, University of Illinois, Northwestern, and University of Wisconsin-Madison. Regardless of the center's location, its success will be determined by the strength of its staff and its surrounding social network infrastructure.

\section{References}

Association of University Technology Managers (AUTUM). (2004). Recollections: Celebrating the history of AUTM and the legacy of Bayh-Dole. Northbrook, Ill.: Association of University Technology Managers.

Audretsch, D. B., Keilbach, M., \& Lehmann, E. (2006). Entrepreneurship and economic growth. New York: Oxford University Press.

Fishback, Bo., Christine, A., Gulbranson, R. E., Litan, L. M., \& Marisa P. (2007). Finding business "idols”: A new model to accelerate start-ups, Kauffman Foundation Report, 4.

Friedman, T. L. (2005). The world is flat. London: Lane. 
Litan, R. E., Lesa M., \& Reedy E. J. (2007). The University as innovator: Bumps in the road, Issues in Science and Technology, Summer, 57-66.

Lucas, R. (1993). Making a miracle. Econometrica, 61, 251-272.

Romer, P. (1986). Increasing returns and long-run growth. Journal of Political Economy, 94, 1002-1037. Thurow, L. (2002). Fortune favors the bold. New York: HarperCollins. 